\title{
Synthesis of peptides with narrow molecular weight distributions via exopeptidase-catalyzed aminolysis of hydrophobic amino-acid alkyl esters
}

\author{
Sachiko Nitta ${ }^{1}$, Ayaka Komatsu ${ }^{1}$, Taisei Ishii ${ }^{1}$, Hiroyuki Iwamoto ${ }^{1}$ and Keiji Numata ${ }^{2}$ \\ A new synthesis technique that produces homogeneous oligopeptides that are essential for the formation of self-assembled \\ structures is described. In contrast with endopeptidases, exopeptidases, which catalyze the cleavage of terminal peptide bonds, \\ can potentially prevent unexpected hydrolysis during aminolysis. This is the first report on exopeptidase-catalyzed oligopeptide \\ synthesis. Oligo(L-leucine) was synthesized using the exopeptidase carboxypeptidase Y (CPDY), which also prevented enzymatic \\ hydrolysis. A high yield of oligo(L-leucine) with a narrow polydispersity (PDI) was obtained by limiting polypeptide cleavage \\ during aminolysis. The reaction conditions, such as the temperature, $\mathrm{pH}, \mathrm{CPDY}$ and substrate concentrations, were optimized to \\ produce the best yields, molecular weights and PDI of the oligomers. Hydrophobic L-leucine methyl ester and L-isoleucine methyl \\ ester were found to be the appropriate substrates for CPDY-catalyzed oligomerization; however, no oligomers were obtained using \\ hydrophilic amino-acid esters. Oligomer yields were also affected by the amino-acid ester groups. Remarkably, the PDI of the \\ oligomers was as low as 1.0, regardless of the reaction conditions and types of substrates used. Thus, exopeptidase-catalyzed \\ oligomerization may become an alternative route for the current endopeptide-catalyzed oligomerization of peptides.
}

Polymer Journal (2016) 48, 955-961; doi:10.1038/pj.2016.52; published online 1 June 2016

\section{INTRODUCTION}

Several types of peptide-based materials have been designed, synthesized and applied in several fields, including the biomedical field, because of their unique chemical, physical and biological properties, which differ from those of synthetic polymers. ${ }^{1-3}$ These materials can be used as biomaterials, such as scaffolds and drug delivery carriers, because of their biocompatibility, biodegradability and stimuli-responsiveness. ${ }^{4-6}$ Both poly- and oligopeptides are promising materials that function as building blocks for the formation of self-assembled nanostructures with stimuli-responsiveness because peptides exhibit self-assembly in aqueous solutions and form distinct structures such as hydrogels, ${ }^{1,3}$ micelles ${ }^{7}$ and fibers. ${ }^{2,4,8,9}$ In addition to homopeptides, the syntheses of a variety of heteropeptides such as block, star and branched peptides have been reported by several researchers. $8,10,11$

Peptides are often chemically synthesized by processes such as solid-phase synthesis, ${ }^{12}$ ring-opening polymerization of $N$-carboxyanhydrides ${ }^{13}$ and recombinant synthesis. ${ }^{14,15}$ Although these methods have both drawbacks and beneficial aspects, the protease-catalyzed chemoenzymatic synthesis of peptides is an alternative to these conventional methods. ${ }^{10,16-20}$ Importantly, this method offers advantages over other processes because it requires limited or no side-chain protection of amino acids. ${ }^{21}$ In addition, this alternative uses mild conditions and retains stereospecificity.

Proteases are the most commonly used catalysts to form peptide bonds during the chemoenzymatic synthesis of peptides. A kinetic model for serine protease-catalyzed peptide synthesis has been proposed. ${ }^{19,22-26}$ This model suggests that the protease-catalyzed synthesis of peptides proceeds via kinetically controlled synthesis. The activated amino acid and the enzyme first form an acyl-enzyme intermediate (ES complex) (Scheme 1), which is then competitively deacylated by a nucleophile or water. If the $\mathrm{N}$ terminus of the amino acid acts as the nucleophile, a new peptide bond is formed; however, if water acts as the nucleophile, then the reaction is terminated. Because of the high yields of coupling products made by this method, even in water, most peptides generated by kinetically controlled synthesis produce an activated enzyme-bound covalent intermediate.

There are two types of proteases, endopeptidases and exopeptidases. The use of endopeptidases, which are often used as catalysts in kinetically controlled synthesis-based polypeptide synthesis, unavoidably leads to the hydrolysis of the polypeptide during polymerization. In such cases, the molecular weight of the polypeptide can be limited to a certain extent. ${ }^{10,21}$ In contrast, an exopeptidase only cleaves terminal peptide bonds. Therefore, we assume that a

\footnotetext{
${ }^{1}$ Department of Biotechnology, Fukuyama University, Hiroshima, Japan and ${ }^{2}$ Enzyme Research Team, RIKEN Center for Sustainable Resource Science, Saitama, Japan Correspondence: Dr S Nitta, Department of Biotechnology, Fukuyama University, 1 Sanzo, Gakuen-cho, Fukuyama, Hiroshima 729-0292, Japan. E-mail: nitta@fubac.fukuyama-u.ac.jp

or Dr K Numata, Enzyme Research Team, RIKEN Center for Sustainable Resource Science, 2-1 Hirosawa, Wako-shi, Saitama 351-0198, Japan. E-mail: keiji.numata@riken.jp

Received 22 February 2016; revised 21 March 2016; accepted 1 April 2016; published online 1 June 2016
} 


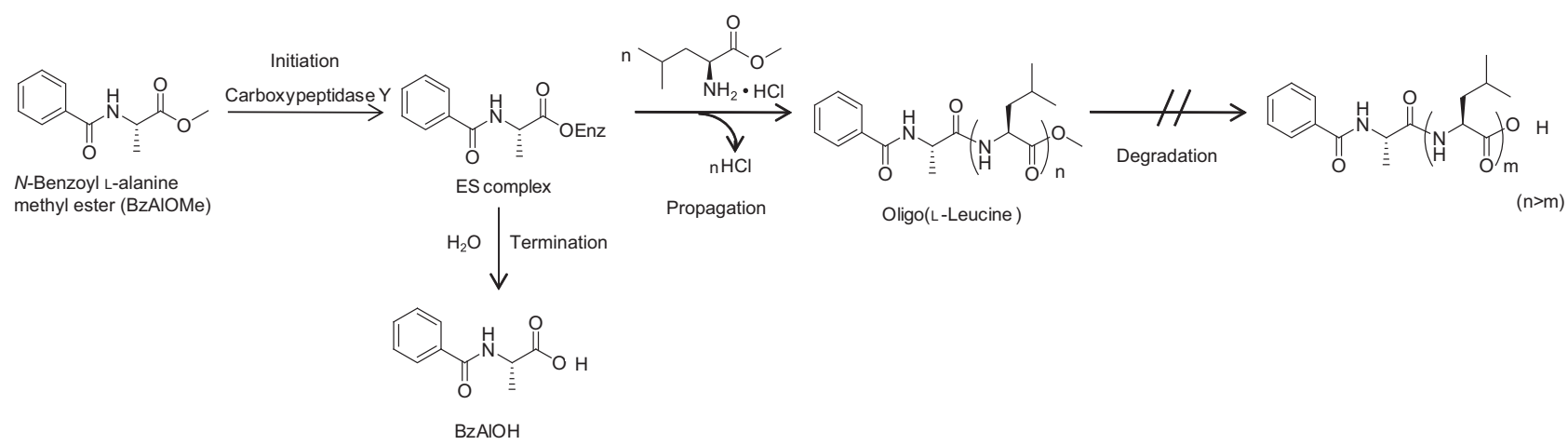

Scheme 1 Carboxypeptidase-catalyzed synthesis of oligopeptides from $\mathrm{N}$-benzoyl L-alanine methyl ester and L-leucine methyl ester.

decrease in the molecular weight of the synthesized polypeptide during the reaction could be avoided.

A high yield from an exopeptidase-catalyzed aminolysis reaction is accomplished by the tight binding of the nucleophile to the enzyme, preferably in a mode that secures an efficient attack on the ES complex. ${ }^{27}$ Thus, it is critical to explore suitable substrates and optimal reaction conditions for the exopeptidase-catalyzed oligomerization to efficiently produce the peptides. However, exopeptidase-catalyzed aminolysis for the synthesis of poly- and oligopeptides has never been optimized to prevent the hydrolysis of the resultant poly- and oligopeptides.

Here, we present the exopeptidase-catalyzed oligomerization of amino-acid alkyl esters using carboxypeptidase Y (CPDY) as an exopeptidase catalyst. CPDY, a serine enzyme that forms ES complexes with amino-acid alkyl esters, is known to have high catalytic activity with a broad amino-acid specificity. ${ }^{28,29}$ Thus, we assumed that the CPDY-catalyzed oligomerization of amino-acid alkyl esters may proceed without the hydrolysis of the formed oligopeptides, which would result in the formation of oligopeptides with a relatively narrow molecular weight distribution in high yields. To achieve our goal, the optimization of the reaction conditions for CPDY-catalyzed oligomerization was studied in detail by analyzing the oligomer yields and the molecular weights of the products.

\section{EXPERIMENTAL PROCEDURE}

\section{Materials}

$N$-Benzoyl L-alanine methyl ester (BzAlOMe), L-leucine methyl ester hydrochloride (L-LeuMe), L-isoleucine methyl ester hydrochloride, L-valine methyl ester hydrochloride, L-leucine ethyl ester hydrochloride, CPDY (peptidyl-L-amino-acid hydrolase EC 3.4.16.1; source, yeast; $136 \mathrm{U} \mathrm{mg}^{-1}$ protein; molecular weight $60 \mathrm{kDa}$ ), deuterated dimethyl sulfoxide, acetonitrile, methanol, dimethyl sulfoxide and ethanol were all purchased from Wako Pure Chemical Industries (Tokyo, Japan). All chemicals were used as received and were of the highest analytical grade.

\section{Nuclear magnetic resonance}

The proton nuclear magnetic resonance spectra obtained were recorded using a Varian NMR System $300(300 \mathrm{MHz})$ spectrometer (Varian Medical Systems, Palo Alto, CA, USA) at $25^{\circ} \mathrm{C}$. The lyophilized samples were solubilized in deuterated dimethyl sulfoxide containing $1 \%$ trifluoroacetic acid at $10 \mathrm{mg} \mathrm{ml}^{-1}$. In total, 32 scans were recorded. The proton chemical shifts were measured in reference to trimethylsilane at 0.00 p.p.m.

The weight-average molecular weight $\left(M_{\mathrm{w}}\right)$, the number-average molecular weight $\left(M_{\mathrm{n}}\right)$ and the polydispersity (PDI) $\left(M_{\mathrm{w}} / M_{\mathrm{n}}\right)$ of the oligopeptides were measured with reverse-phase high-performance liquid chromatography (RP-HPLC) using an ODS-80 $\mathrm{T}_{\mathrm{M}}$ column (TOSOH, Tokyo, Japan) with a UV detector. The oligopeptides were eluted with a linear gradient of $30 \%$ acetonitrile in acetic acid buffer (20 mM, $\mathrm{pH} 4)$ to $100 \%$ acetonitrile over $20 \mathrm{~min}$ at a flow rate of $1.0 \mathrm{ml} \mathrm{min}^{-1}$ and were detected at $245 \mathrm{~nm}$.

The molecular weights of the components of each peak were determined by liquid chromatography-mass spectrometry using a Wakosil-5C18 column (Wako Pure Chemical Industries, Tokyo, Japan). The analytical conditions were the same as those described for RP-HPLC. The liquid chromatographymass spectrometry system was calibrated using cesium iodide $\left(0.5 \mathrm{mg} \mathrm{ml}^{-1}\right)$ and sodium iodide $\left(2 \mathrm{mg} \mathrm{ml}^{-1}\right)$ in isopropanol/water $\left(1: 1\left(\mathrm{v} \mathrm{v}^{-1}\right)\right)$. The yields of BzAlOMe, the hydrolyzed product of BzAlOMe (BzAlOH) and the oligomers were calculated from the peak areas of each compound eluted during RP-HPLC.

\section{Polymerization of amino-acid esters}

The general procedure for the oligomerization of L-LeuMe was performed as follows: L-LeuMe $(0.4 \mathrm{M})$ in carbonate buffer $(160 \mu \mathrm{l}, 1.2 \mathrm{M}, \mathrm{pH} 10)$ was added to a solution of BzAlOMe $(50 \mathrm{~mm})$ in methanol $(20 \mu \mathrm{l})$, followed by the addition of CPDY in carbonate buffer $\left(1.0 \mathrm{mg} \mathrm{m}^{-1}\right)$. The mixture was stirred at a constant rate at $30{ }^{\circ} \mathrm{C}$ for $60 \mathrm{~min}$. After the reaction was complete, a white precipitate was obtained and purified by centrifugal separation. The product was then lyophilized overnight. Then, a time-course study was performed on the CPDY-mediated oligopeptides that were obtained. During the reaction, aliquots $(10 \mu \mathrm{l})$ of the reaction mixture were taken at appropriate intervals, added to acetonitrile $(50 \mu \mathrm{l})$ and mixed to render the product soluble. These samples were used for the quantitative analysis of the reaction products by RP-HPLC.

\section{RESULTS AND DISCUSSION}

Following the synthesis mechanism shown in Scheme 1, an N-protected amino acid, BzAlOMe (amine component), was mixed with a hydrophobic amino alkyl ester and L-LeuMe (nucleophile), and the reaction was catalyzed by CPDY in an alkaline buffer. Theoretically, BzAlOMe reacts first with CPDY to form an acyl-enzyme intermediate. In the second step, this active ester intermediate reacts with either L-LeuMe to form oligo(L-leucine) (aminolysis) or with water to form BzAlOH (hydrolysis). ${ }^{25,30}$ An efficient nucleophilic reaction requires that the amino-acid carboxyl groups do not ionize or form a zwitterion. Previous reports have examined the effect of nucleophiles with different carboxyl groups on aminolysis reaction yields using N-protected peptide alkyl esters. ${ }^{30,31}$ Among the amino-acid alkyl esters, amino-acid amides and free amino acids, amino-acid alkyl esters were the most suitable substrate for oligomerization because the resulting peptide was obtained directly in an ester form and was ready to react with the enzyme again, leading to consecutive additions of the same nucleophile. Thus, amino-acid methyl esters were chosen as the nucleophiles in this study.

The proton nuclear magnetic resonance spectrum of oligo (L-leucine) that was synthesized using CPDY (0.2 M L-LeuMe, $50 \mathrm{~mm}$ BzAlOMe, $0.5 \mathrm{mg} \mathrm{ml}^{-1}$ CPDY and $1.2 \mathrm{M}$ carbonate buffer ( $\mathrm{pH} 10$ ) 


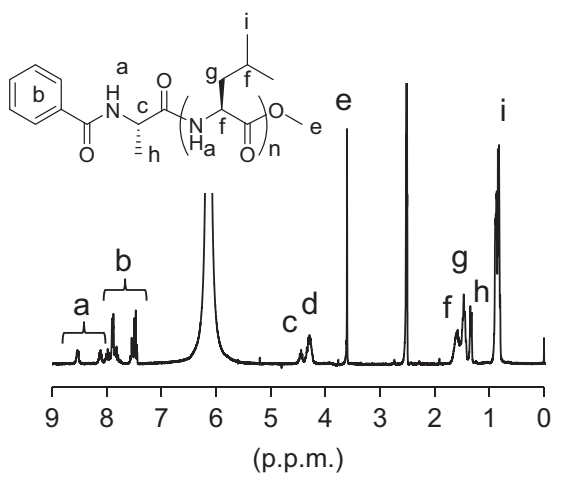

Figure 1 Proton nuclear magnetic resonance ( $\left.{ }^{1} \mathrm{H}-\mathrm{NMR}\right) \quad(300 \mathrm{MHz}$, deuterated dimethyl sulfoxide (DMSO- $\left.d_{6}\right)$ ) spectrum of oligo(L-leucine) synthesized from $\mathrm{N}$-benzoyl L-alanine methyl ester (BzAlOMe) and L-leucine methyl ester. The reaction was conducted using $0.2 \mathrm{~m}$ L-leucine methyl ester hydrochloride (L-LeuMe), $50 \mathrm{~mm}$ BzAlOMe and $0.5 \mathrm{mg} \mathrm{ml}^{-1}$ carboxypeptidase $\mathrm{Y}$ (CPDY) in $1.2 \mathrm{~m}$ carbonate buffer $(\mathrm{pH} 10)$ at $30^{\circ} \mathrm{C}$ for $2 \mathrm{~h}$.

incubated at $30{ }^{\circ} \mathrm{C}$ for $2 \mathrm{~h}$ ) is shown in Figure 1. Methine group peaks from the alanine groups of BzAlOMe (c) and the leucine groups of L-leucine methyl ester (d) were detected at 4.45 and 4.31 p.p.m., respectively, indicating that the product obtained possessed both alanine and leucine groups and that BzAlOMe reacted with L-LeuMe. The terminal methyl groups of L-leucine methyl ester (e) were detected as a peak at 3.60 p.p.m., indicating that the hydrolysis of the leucine methyl esters was limited. The terminal benzoyl groups and the amide groups of oligomer chains were also detected as peaks at 7.50-7.90 and 7.98-8.53 p.p.m., respectively.

The molecular weight of oligo(L-leucine) was determined using RP-HPLC and liquid chromatography-mass spectrometry. As shown in Figure 2, the oligo(L-leucine) peptide had a repeat unit number from 1 to 6 . It was confirmed that the oligo(L-leucine) peptide possessed terminal benzoyl groups. The yields of the remaining BzAlOMe, the hydrolytic product of BzAlOMe $(\mathrm{BzAlOH})$, and the oligomers were calculated using the ratios of peak areas of each component obtained by HPLC. BzAlOMe and BzAlOH were detected at retention times of 4.8 and $2.5 \mathrm{~min}$, respectively. The oligomer yield was calculated by subtracting the yields of BzAlOMe and $\mathrm{BzAlOH}$ from the total peak areas.

As the reaction proceeded, insoluble white precipitates formed. This prompted the equilibrium of the reaction to shift towards peptide synthesis, which may have led to higher yields of the oligomers. This can be explained by a mechanism in which the elimination of the reaction product as an insoluble material could be the thermodynamic driving force toward synthesis. In contrast, oligomer precipitation also diminished the oligomer's accessibility to CPDY, which may have limited the oligomer chain lengths. ${ }^{17,32}$

The miscibility of substrates is an important factor for chemoenzymatic polymerization because the reaction usually proceeds in a homogeneous phase. ${ }^{20}$ Because of the low solubility of BzAlOMe in the buffer, BzAlOMe was first dissolved in water-miscible organic solvents before the addition of an L-LeuMe solution in buffer. When BzAlOMe was dissolved in methanol, dimethyl sulfoxide, ethanol or acetonitrile, the oligomer yields were $76.6 \%, 54.3 \%, 26.6 \%$ and $0 \%$, respectively, indicating that methanol was the most suitable solvent for dissolving BzAlOMe. The concentration of water-miscible solvents is known to affect the catalytic activity of proteases. In particular, the addition of methanol to the enzymatic reaction mixtures denatures

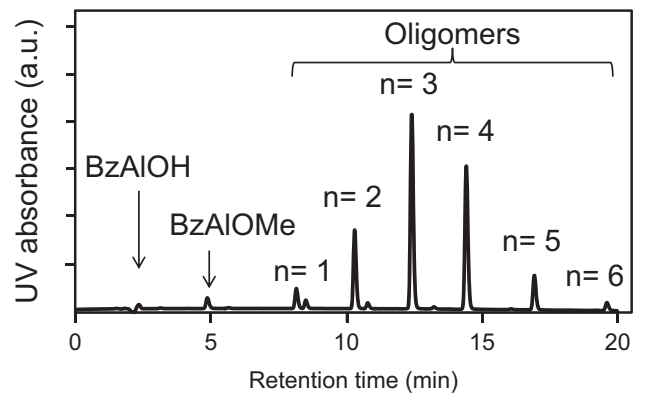

Figure 2 High-performance liquid chromatography (HPLC) analysis of oligo(L-leucine) synthesized from $\mathrm{N}$-benzoyl L-alanine methyl ester (BzAlOMe) and L-leucine methyl ester. The reaction was conducted using $0.2 \mathrm{~m}$ L-leucine methyl ester hydrochloride (L-LeuMe), $50 \mathrm{~mm}$ BzAIOMe and $0.5 \mathrm{mg} \mathrm{ml}^{-1}$ carboxypeptidase $Y$ (CPDY) in $1.2 \mathrm{M}$ carbonate buffer (pH 10) at $30^{\circ} \mathrm{C}$ for $2 \mathrm{~h}$.

CPDY and renders it inactive because of an irreversible change in the flexible conformation of the enzyme. ${ }^{33}$ Thus, we also examined the effect of the volume of methanol used on oligomer yields. The oligomer yields were $76.6 \%, 2.84 \%$ and $1.02 \%$ when the BzAlOMe concentrations in methanol were 500, 200 and $100 \mathrm{~mm}$, respectively, which indicated that a low concentration of BzAlOMe in methanol markedly diminished CDPY activation.

Although it is often difficult to control the molecular weights or the yields of oligomers in exopeptidase-catalyzed oligomerizations, the optimization of the reaction conditions, such as the reaction temperature, buffer $\mathrm{pH}$, and the monomer and catalyst concentrations, may result in an increase in the molecular weights and yields of peptides by diminishing the hydrolysis of oligomers. Therefore, we examined how these factors molecularly affected the oligomers in greater detail.

\section{Time-course analysis of oligo(L-leucine) synthesis}

To investigate the time course of oligo(L-leucine) synthesis, $0.5 \mathrm{mg} \mathrm{ml}^{-1} \mathrm{CPDY}, 50 \mathrm{~mm}$ BzAlOMe and $0.2 \mathrm{M} \mathrm{L}$-LeuMe were incubated at $30^{\circ} \mathrm{C}$ in carbonate buffer $(1.2 \mathrm{M}, \mathrm{pH} 10)$. As shown in Figure 3, BzAlOMe reacted rapidly with L-LeuMe, and after 10 and $30 \mathrm{~min}$, the yields had reached $65.6 \%$ and $76.6 \%$, respectively. A further increase in the reaction duration beyond $60 \mathrm{~min}$ showed no substantial increase in oligomer yields. Unlike oligomer yields, the BzAlOH yield was $>25 \%$, regardless of the reaction time. The molecular weight increased slightly from $577 \mathrm{Da}$ at $10 \mathrm{~min}$ to $623 \mathrm{Da}$ at $120 \mathrm{~min}$, and the enzymatic hydrolysis of peptide bonds did not occur. It was also confirmed that the PDI of the oligo(L-leucine) $\left(M_{\mathrm{w}} / M_{\mathrm{n}}\right)$ peptide was close to 1.0 , regardless of the reaction time. These data agree with our assumption that hydrolysis of the oligomer backbone would not occur during exopeptidase-catalyzed oligomerization. Furthermore, the rapid oligomerization of L-LeuMe initiated by BzAlOMe is an important aspect of the enzymatic polymerization because it contributes to an environmentally friendly synthesis and to its low-energy and atom-economical characteristics. Although the reaction proceeded rapidly, experiments were carried out after $2 \mathrm{~h}$ to confirm that the product yields remained constant under each condition.

\section{Effect of reaction temperature}

The effects of reaction temperature on the oligomer yields and the molecular weights were examined to determine the optimal reaction temperature. As shown in Figure 4, as the reaction temperature 
increased from 20 to $50{ }^{\circ} \mathrm{C}$, the yield of the oligo(L-leucine) peptide decreased from 78.3 to $4.0 \%$. In contrast, the yields of $\mathrm{BzAlOH}$ increased from 18.6 to $93.4 \%$ with an increase in temperature. The molecular weights of oligo(L-leucine) decreased as the reaction temperature increased from 20 to $50^{\circ} \mathrm{C}$. These results indicated that the hydrolysis of ester groups was enhanced relative to amide synthesis at high temperatures because of the inactivation of CPDY.

\section{Effect of buffer $\mathrm{pH}$}

CPDY has been reported to catalyze peptide bond formation from $\mathrm{N}$-protected amino-acid derivatives under alkaline conditions. ${ }^{29}$ Thus, the effect of buffer $\mathrm{pH}$ at alkaline conditions $(\mathrm{pH}=7-10)$ on the yields
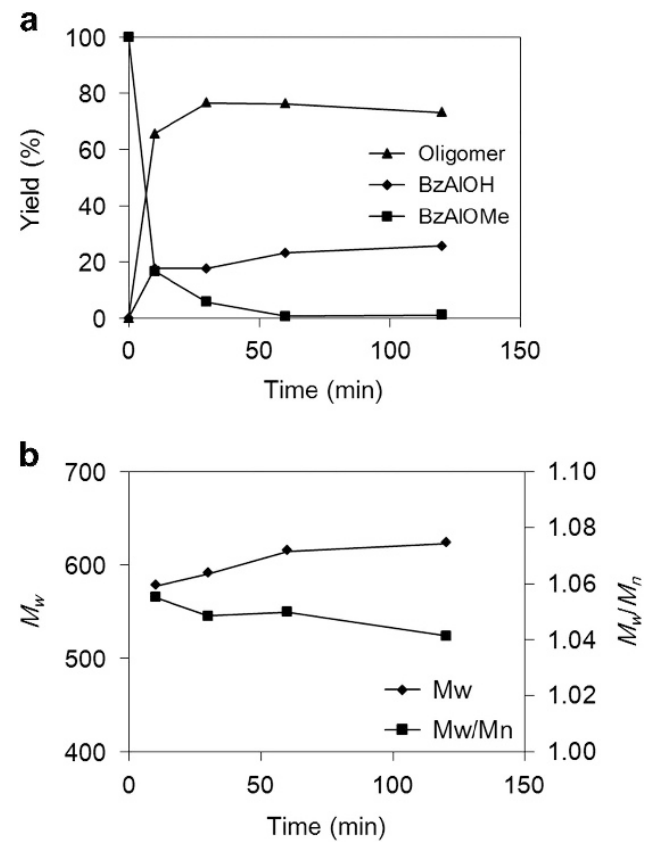

Figure 3 (a) Time course of yields of oligomer, hydrolyzed product of BzAlOMe (BzAIOH) and $N$-benzoyl L-alanine methyl ester (BzAlOMe) during carboxypeptidase $Y$ (CPDY)-catalyzed polymerization. (b) Time course of the weight-average molecular weight $\left(M_{\mathrm{w}}\right)$ and $M_{\mathrm{w}} / M_{\mathrm{n}}$ of oligomers during CPDYcatalyzed polymerization. The reactions were conducted using $0.2 \mathrm{M}$ L-leucine methyl ester hydrochloride (L-LeuMe), $50 \mathrm{~mm} \mathrm{BzAlOMe}$ and $0.5 \mathrm{mg} \mathrm{ml}^{-1}$ CPDY in $1.2 \mathrm{M}$ carbonate buffer $(\mathrm{pH} 10)$ at $30^{\circ} \mathrm{C}$. $M_{\mathrm{n}}$, number-average molecular weight.

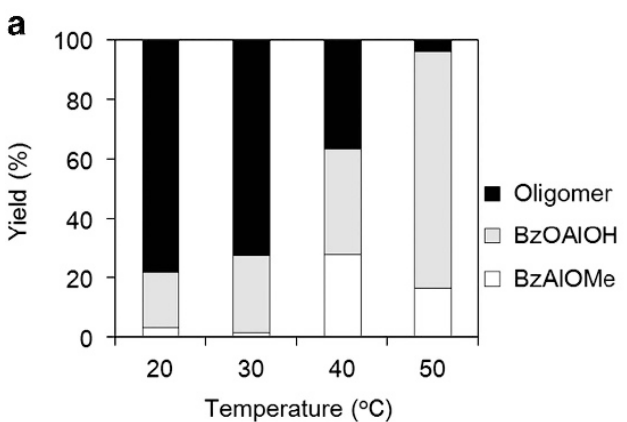

and the molecular weights of oligo(L-leucine) were examined. When L-LeuMe acts as a nucleophile to form a peptide bond, $\mathrm{HCl}$ is released, and the acidity of the solution increases. Thus, the salt concentration of the buffer was set to $1.2 \mathrm{M}$ in this study, which was relatively higher than that used in other enzymatic polymerization reactions to avoid a decrease in $\mathrm{pH}$ during oligomerization. It should be noted here that it was previously reported that the effect of salt concentration on CPDY-catalyzed reactions is negligible. ${ }^{34}$

As shown in Figure 5, the oligomer yields increased from 18.5 to $72.7 \%$ as the buffer $\mathrm{pH}$ increased from 7 to 10 . The maximum product yield was obtained with initial $\mathrm{pH}$ values ranging from 9 to 10. At a low $\mathrm{pH}$, the hydrolysis of BzAlOMe was favored over oligomerization, indicating that the esterase activity of CPDY was higher compared with its protease activity at a low $\mathrm{pH}$. No relationship was observed between the buffer $\mathrm{pH}$ and the oligo(L-leucine) molecular weight.

\section{CPDY concentration}

The yields of oligo(L-leucine) increased from 56.8 to $76.7 \%$ as the concentration of CPDY increased from 0.1 to $1.5 \mathrm{mg} \mathrm{ml}^{-1}$, whereas the molecular weight of the oligo(L-leucine) peptide obtained increased as the CPDY concentration increased from 0.1 to $1.0 \mathrm{mg} \mathrm{ml}^{-1}$ but decreased slightly at $1.5 \mathrm{mg} \mathrm{ml}^{-1}$ (Figure 6). The lower yield of the oligomer that was obtained at lower CPDY concentrations was due to the enhanced non-enzymatic hydrolysis of BzAlOMe, which was a result of the aminolysis reaction proceeding so slowly that BzAlOMe was exposed to a high buffer $\mathrm{pH}$ for an extended period of time. At high CPDY concentrations, an excess of acyl-enzyme intermediates may have resulted in a decrease in the molecular weight of the oligomer.

\section{Substrate concentration}

Figure 7 shows the effect of the BzAlOMe concentration on the yield and molecular weight of the oligo(L-leucine) peptide obtained. The yield of oligomer decreased from 83.2 to $45.3 \%$ with an increase in the BzAlOMe concentration from 5 to $100 \mathrm{~mm}$. Similarly, the molecular weight of the oligomer decreased from 692 to $555 \mathrm{Da}$ as the concentration of BzAlOMe increased from 5 to $100 \mathrm{~mm}$. As the BzAlOMe concentration decreased from 100 to $5 \mathrm{~mm}$, the feed ratio of L-LeuMe/BzAlOMe increased from 4.0 to 80.0 when the L-LeuMe concentration was held constant $(0.4 \mathrm{M})$. As the L-LeuMe/BzAlOMe ratio increased, the number of $\mathrm{L}$-LeuMe molecules that could react with one BzAlOMe molecule increased, which increased the oligomer's molecular weight. Relatively low concentrations of

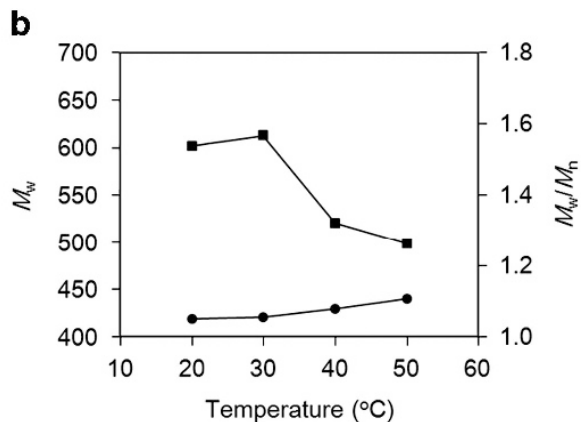

Figure 4 (a) Effect of the reaction temperature on yields of oligomer, hydrolyzed product of BzAlOMe (BzAlOH) and $N$-benzoyl L-alanine methyl ester (BzAIOMe) after polymerization. (b) Effect of the reaction temperature on the weight-average molecular weight $\left(M_{\mathrm{w}}\right)$ of oligomers. The reactions were conducted using $0.2 \mathrm{~m}$ L-leucine methyl ester hydrochloride (L-LeuMe), $50 \mathrm{~mm}$ BzAlOMe and $0.5 \mathrm{mg} \mathrm{ml}^{-1}$ carboxypeptidase Y (CPDY) in $1.2 \mathrm{~m}$ carbonate buffer $(\mathrm{pH} 10)$ for $2 \mathrm{~h}$. The squares and circles indicate the $M_{\mathrm{w}}$ and $M_{\mathrm{w}} / M_{\mathrm{n}}$ of oligo(L-leucine), respectively. $M_{\mathrm{n}}$, number-average molecular weight. 
a

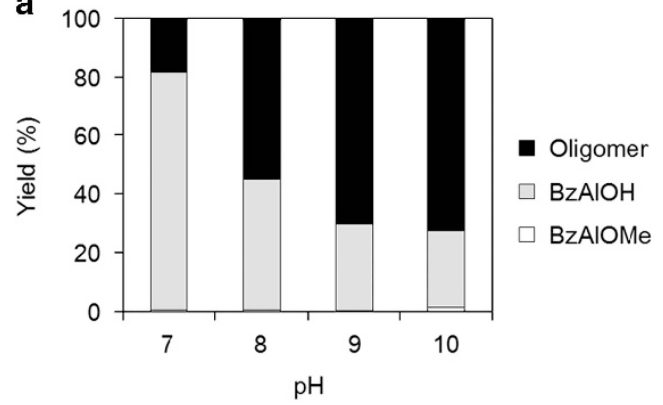

b

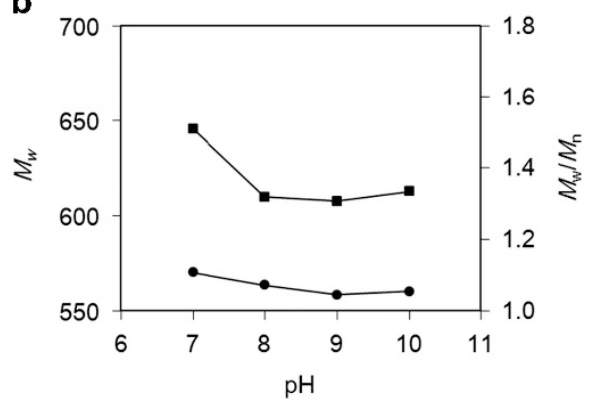

Figure 5 (a) Effect of buffer $\mathrm{pH}$ on yields of oligomer, hydrolyzed product of BzAlOMe (BzAlOH) and $\mathrm{N}$-benzoyl L-alanine methyl ester (BzAlOMe) after polymerization. (b) Effect of buffer $\mathrm{pH}$ on the weight-average molecular weight $\left(M_{\mathrm{w}}\right)$ of oligomers. The reactions were conducted using $0.2 \mathrm{~m} L$-leucine methyl ester hydrochloride (L-LeuMe), $50 \mathrm{~mm} \mathrm{BzAIOMe}$ and $0.5 \mathrm{mg} \mathrm{ml}^{-1}$ carboxypeptidase $\mathrm{Y}$ (CPDY) in $1.2 \mathrm{~m}$ carbonate buffer at $30{ }^{\circ} \mathrm{C}$ for $2 \mathrm{~h}$. The squares and circles indicate the $M_{\mathrm{w}}$ and $M_{\mathrm{w}} / M_{\mathrm{n}}$ of oligo(L-leucine), respectively. $M_{\mathrm{n}}$, number-average molecular weight.
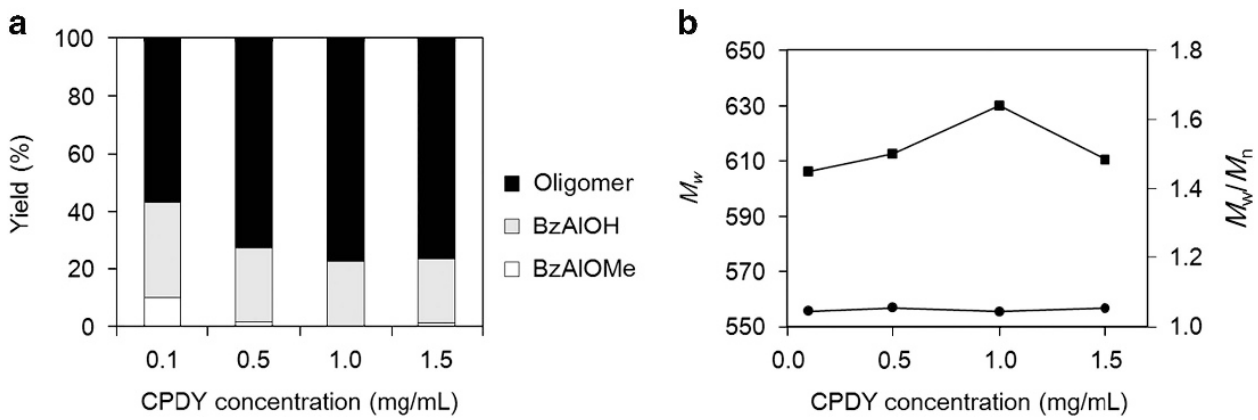

Figure 6 (a) Effect of the carboxypeptidase Y (CPDY) concentration on yields of oligomer, hydrolyzed product of BzAlOMe (BzAlOH) and $\mathrm{N}$-benzoyl L-alanine methyl ester (BzAIOMe) after polymerization. (b) Effect of the CPDY concentration on the weight-average molecular weight $\left(M_{\mathrm{w}}\right)$ of oligomers. The reactions were conducted using $0.2 \mathrm{~m}$ L-leucine methyl ester hydrochloride (L-LeuMe), $50 \mathrm{~mm}$ BzAlOMe and CPDY in $1.2 \mathrm{~m}$ carbonate buffer (pH 10 ) at $30{ }^{\circ} \mathrm{C}$ for $2 \mathrm{~h}$. The squares and circles indicate the $M_{\mathrm{w}}$ and $M_{\mathrm{w}} / M_{\mathrm{n}}$ of oligo(L-leucine), respectively. $M_{\mathrm{n}}$, number-average molecular weight.
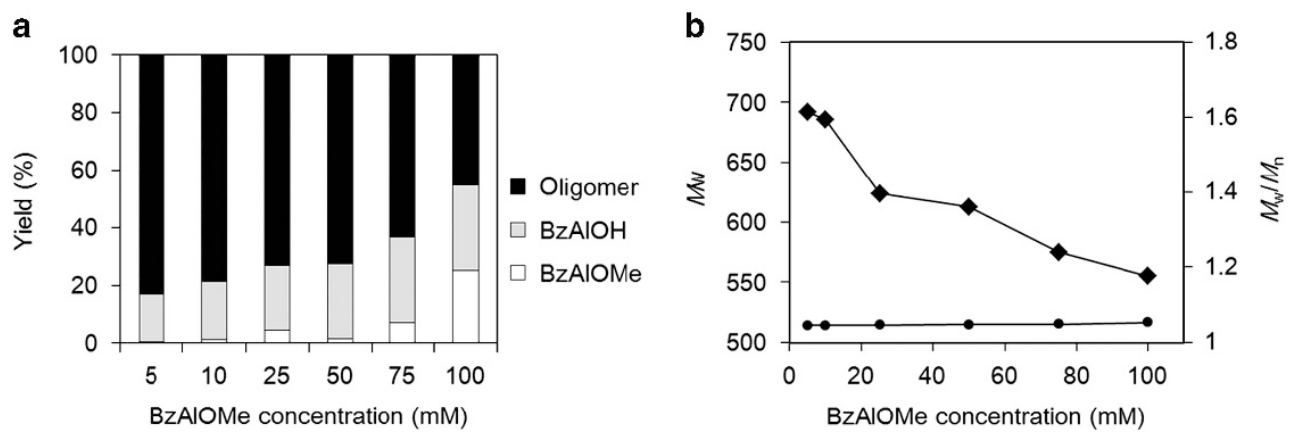

Figure 7 (a) Effect of the $\mathrm{N}$-benzoyl L-alanine methyl ester (BzAlOMe) concentration on yields of oligomer, hydrolyzed product of BzAlOMe (BzAlOH) and BzAIOMe after polymerization. (b) Effect of BzAlOMe concentration on the weight-average molecular weight $\left(M_{w}\right)$ of oligomers. The reactions were conducted using $0.2 \mathrm{M} \mathrm{L-leucine} \mathrm{methyl} \mathrm{ester} \mathrm{hydrochloride} \mathrm{(L-LeuMe),} \mathrm{BzAlOMe} \mathrm{and} 0.5 \mathrm{mg} \mathrm{ml}^{-1}$ carboxypeptidase Y (CPDY) in $1.2 \mathrm{M} \mathrm{carbonate} \mathrm{buffer} \mathrm{(pH} \mathrm{10)} \mathrm{at}$ $30{ }^{\circ} \mathrm{C}$ for $2 \mathrm{~h}$. The diamonds and circles indicate the $M_{\mathrm{w}}$ and $M_{\mathrm{w}} / M_{\mathrm{n}}$ of oligo(L-leucine), respectively. $M_{\mathrm{n}}$, number-average molecular weight.

BzAlOMe produced high yields of oligomer, suggesting that the oligomerization kinetics are sufficiently rapid to allow for product formation without requiring a high substrate concentration to shift the equilibrium toward the products. $^{20}$

The concentration of L-LeuMe also affected the yield and molecular weight of oligo(L-leucine), as shown in Figure 8. The yield of oligomer increased from 49.6 to $85.6 \%$ as the concentration of L-LeuMe increased from 0.1 to $0.6 \mathrm{M}$, whereas the molecular weight increased only slightly from 601 to $620 \mathrm{Da}$, confirming that the aminolysis to hydrolysis ratio was influenced by the nucleophile concentration because aminolysis and hydrolysis are competitive reactions.
Optimal reaction conditions for CPDY-catalyzed oligomerization To prepare oligo(L-leucine) so that it can be used as a building block for the formation of self-assembled nanostructures, it is critical to obtain oligo(L-leucine) with a low PDI in high yields. Previously, the three-dimensional structure of CPDY was obtained using the multiple isomorphous replacement method and crystallographic refinement, and the structure indicated that the side chains of Trp49, Asn51, Glu65 and Glu145 are involved in the recognition of the C-terminal carboxylate group of peptide substrates. ${ }^{35}$ As BzAlOMe binds to the binding site of CPDY, the competitive nucleophilic reactions of the two nucleophiles, water and L-LeuMe, proceed. Thus, to obtain oligo 

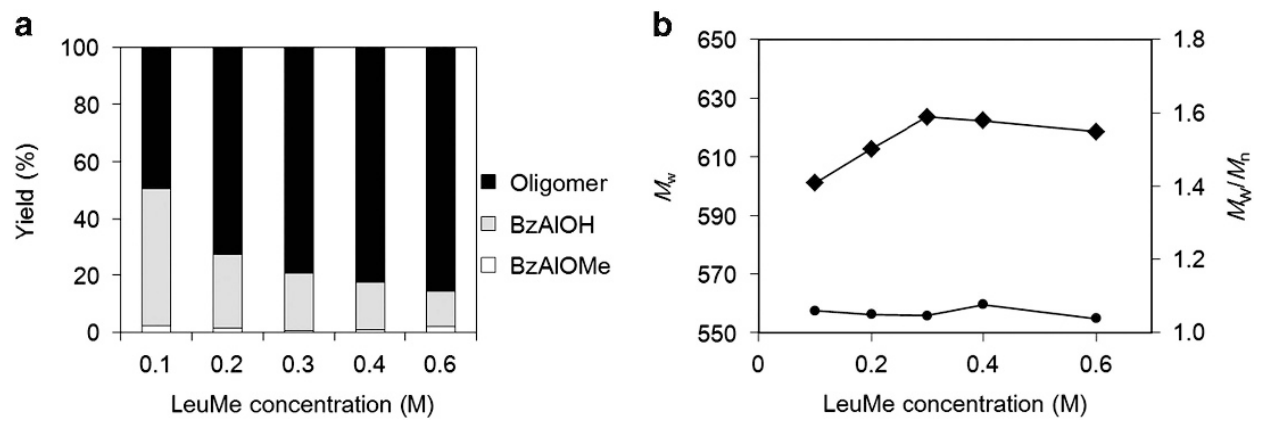

Figure 8 (a) Effect of L-leucine methyl ester hydrochloride (L-LeuMe) concentration on yields of oligomer, hydrolyzed product of BzAlOMe (BzAlOH) and $\mathrm{N}$-benzoyl L-alanine methyl ester (BzAlOMe) after polymerization. (b) Effect of L-LeuMe concentration on the weight-average molecular weight ( $\left.M_{\mathrm{w}}\right)$ of oligomers. The reactions were conducted using L-LeuMe, $50 \mathrm{~mm}$ BzAlOMe and $0.5 \mathrm{mg} \mathrm{ml}^{-1}$ carboxypeptidase $\mathrm{Y}$ (CPDY) in $1.2 \mathrm{M}$ carbonate buffer (pH 10 ) at $30{ }^{\circ} \mathrm{C}$ for $2 \mathrm{~h}$. The diamonds and circles indicate the $M_{\mathrm{w}}$ and $M_{\mathrm{w}} / M_{\mathrm{n}}$ of oligo(L-leucine), respectively. $M_{\mathrm{n}}$, number-average molecular weight.

(L-leucine) in a high yield, it is critical to prevent the hydrolysis of BzAlOMe, which terminates the reaction. As the results in Figures 4-8 demonstrate, the reaction temperature, $\mathrm{pH}$ and L-LeuMe concentration were the main factors that affected the yield of $\mathrm{BzAlOH}$, the hydrolysis product. Lower reaction temperatures and higher $\mathrm{pH}$ values effectively diminished the hydrolysis of BzAlOMe. This trend agrees with a previous report in which the catalytic activity of an exopeptidase, cathepsin C, was investigated in water; this study showed that more acidic conditions favored hydrolysis and that a basic $\mathrm{pH}$ should be used to avoid degradation reactions. ${ }^{24}$ A higher concentration of L-LeuMe was also required to promote the propagation reaction, which occurs when L-LeuMe functions as a nucleophile.

It was also necessary to optimize the reaction conditions to control the molecular weight of the oligo(L-leucine) peptide that is produced and to obtain low PDI values. The results shown in Figures 4-8 demonstrate that the reaction temperature and concentration of BzAlOMe were the main factors that affected the molecular weight of the oligo(L-leucine) peptide that was obtained. At reaction temperatures above the optimal temperature for $\operatorname{CPDY}\left(25^{\circ} \mathrm{C}\right)$, nucleophilic attack by water molecules dominated the propagation reaction. The highest molecular weight oligo(L-leucine) peptide was obtained at a BzAlOMe concentration of $5 \mathrm{~mm}$, indicating that controlling the number of ES complex molecules is the most critical step for increasing the molecular weight of oligo(L-leucine).

It should be noted that the PDI values were as low as 1.0, regardless of the reaction conditions (Figures 4-8). For example, the PDI values for oligo(L-leucine) synthesized with CPDY concentrations of $0.1,0.5$, 1.0 and $1.5 \mathrm{mg} \mathrm{ml}^{-1}$ were $1.045,1.055,1.043$ and 1.053 , respectively. This indicates that cleavage of the peptide bonds of the synthesized oligo(L-leucine) was prevented during the oligomerization, which corresponds to our assumption that exopeptidases could be suitable catalysts for the formation of oligopeptides without causing hydrolysis of the oligopeptide.

\section{Type of amino acids}

To explore the effects of the amino-acid chemical structure on the reactivity of CPDY-catalyzed oligomerizations, $0.2 \mathrm{M} \mathrm{L-LeuMe,}$ L-leucine ethyl ester hydrochloride, L-LysMe, L-isoleucine methyl ester hydrochloride and L-valine methyl ester hydrochloride were each incubated with $50 \mathrm{~mm}$ BzAlOMe and $0.5 \mathrm{mg} \mathrm{ml}^{-1} \mathrm{CPDY}$ at $30^{\circ} \mathrm{C}$ in carbonate buffer $(1.2 \mathrm{M}, \mathrm{pH} 10)$. Under the same conditions, the yield of the oligomer of L-leucine ethyl ester hydrochloride was $15.0 \%$, which was five times lower than that made from L-LeuMe. The increased size of the ester group may have hindered the optimal binding of the amino-acid esters to CPDY, and as a result, hydrolysis dominated. ${ }^{23,32}$ The yields of the oligo(L-leucine), oligo(L-isoleucine) and oligo(L-valine) peptides were $76.6 \%, 81.3 \%$ and $77.9 \%$, respectively, indicating that a small change in the chemical structure of the amino-acid side chains did not influence the aminolysis yields. In contrast, the molecular weights of the oligo(L-leucine), oligo(L-isoleucine) and oligo(L-valine) peptides were 612, 680 and $620 \mathrm{Da}$, respectively. Although L-LeuMe and L-isoleucine methyl ester hydrochloride have the same molecular weight and $\mathrm{pKa}$, it was presumed that the difference in the molecular weights of the oligo (L-leucine) and oligo(L-isoleucine) peptides was due to the difference in oligomer solubility, as the water solubility of L-Leu and L-Ile at $25^{\circ} \mathrm{C}$ is 2.19 and $4.12 \mathrm{~g}$ per $100 \mathrm{~g}$ water, respectively. The higher solubility of oligo(L-isoleucine) resulted in a promotion in aminolysis without precipitation from the reaction mixture, which led to an increase in the molecular weight of the product. In the same manner, when a hydrophilic amino acid, L-LysMe, was reacted with BzAlOMe, the yield of oligomer was as low as $0 \%$, and hydrolysis of BzAlOMe dominated. This corresponds to the findings from a previous report that showed that CPDY prefers to react with hydrophobic amino acids as opposed to hydrophilic amino acids. ${ }^{31}$ These data indicated that CPDY-catalyzed oligomerization was affected by both the type of amino acid and the size of the ester groups.

\section{CONCLUSION}

The CPDY-catalyzed oligomerization of L-LeuMe was performed in $1.2 \mathrm{M}$ carbonate buffer at $30^{\circ} \mathrm{C}$ to produce oligo(L-leucine) with a $78 \%$ yield in $30 \mathrm{~min}$. BzAlOMe, which functioned as the amine component, first formed an ES complex with CPDY, and then L-LeuMe attacked the complex to produce oligo(L-leucine). The yields and molecular weights of oligo(L-leucine) were affected by the reaction temperature, buffer $\mathrm{pH}$, and substrate and CPDY concentrations, as demonstrated by RP-HPLC. Regardless of the conditions, however, the PDI was always low, with a value of 1.0, indicating that exopeptidase-catalyzed oligomerization produced oligopeptides without frequent cleavages of the internal peptide bonds. We also demonstrated that CPDY-catalyzed oligomerization was affected by the type of amino acid as well as the size of the amino-acid ester groups. These results indicate that exopeptidase-catalyzed oligomerization is a new route for the synthesis of oligopeptides with a relatively narrow molecular weight distribution.

\section{CONFLICT OF INTEREST}

The authors declare no conflict of interest. 


\section{ACKNOWLEDGEMENTS}

Dr Takashi Nishiyama and Dr Masaya Ohta assisted with the nuclear magnetic resonance and LCMS analyses, respectively. This work was supported by a Grant-in-Aid for JSPS Fellows.

1 Yan, C. \& Pochan, D. J. Rheological properties of peptide-based hydrogels for biomedical and other applications. Chem. Soc. Rev. 39, 3528-3540 (2010).

2 Kasai, S., Ohga, Y., Mochizuki, M., Nishi, N., Kadoya, Y. \& Nomizu, M. Multifunctional peptide fibrils for biomedical materials. Pept. Sci. 76, 27-33 (2004).

3 Pinto Reis, C., Neufeld, R. J., Ribeiro, A. J. \& Veiga, F. Nanoencapsulation II. Biomedical applications and current status of peptide and protein nanoparticulate delivery systems. Nanomedicine 2, 53-65 (2006).

4 Cui, H., Webber, M. J. \& Stupp, S. I. Self-assembly of peptide amphiphiles: from molecules to nanostructures to biomaterials. Pept. Sci. 94, 1-18 (2010).

5 Woolfson, D. N. \& Ryadnov, M. G. Peptide-based fibrous biomaterials: some things old new and borrowed. Curr. Opin. Chem. Biol. 10, 559-567 (2006).

6 Holmes, T. C. Novel peptide-based biomaterial scaffolds for tissue engineering. Trends Biotechnol. 20, 16-21 (2002).

7 Hartgerink, J. D., Beniash, E. \& Stupp, S. I. Self-assembly and mineralization of peptide-amphiphile nanofibers. Science 294, 1684-1688 (2001).

8 Carlsen, A. \& Lecommandoux, S. Self-assembly of polypeptide-based block copolymer amphiphiles. Curr. Opin. Colloid Interface Sci. 14, 329-339 (2009).

9 Vauthey, S., Santoso, S., Gong, H., Watson, N. \& Zhang, S. Molecular self-assembly of surfactant-like peptides to form nanotubes and nanovesicles. Proc. Natl Acad. Sci. USA 99, 5355-5360 (2002).

10 Fagerland, J., Finne-Wistrand, A. \& Numata, K. Short one-pot chemo-enzymatic synthesis of L-lysine and L-alanine diblock co-oligopeptides. Biomacromolecules 15 735-743 (2014).

11 Lin, Y.-A., Ou, Y.-C., Cheetham, A. G. \& Cui, H. Supramolecular polymers formed by ABC miktoarm star peptides. ACS Macro Lett. 2, 1088-1094 (2013).

12 Merrifield, R. B. in Advances in Enzymology and Related Areas of Molecular Biology (ed.Purich, D.) Ch. 6, 221-296 (Wiley, Hoboken, NJ, USA, 2006).

13 Cheng, J. \& Deming, T. in Peptide-Based Materials (ed. Deming, T.) 1-26 (Springer, Berlin, Heidelberg, Germany, New York, NY, USA, 2012).

14 Lepage, P., Heckel, C., Humbert, S., Stahl, S. \& Rautmann, G. Recombinant technology as an alternative to chemical peptide synthesis: expression and characterization of HIV-1 rev recombinant peptides. Anal. Biochem. 213, 40-48 (1993).

15 Numata, K., Hamasaki, J., Subramanian, B. \& Kaplan, D. L. Gene delivery mediated by recombinant silk proteins containing cationic and cell binding motifs. J. Control Rel. 146, 136-143 (2010)

16 Aso, K. \& Kodaka, H. Trypsin-catalyzed oligomerization of L-lysine esters. Biosci. Biotechnol. Biochem. 56, 755-758 (1992).

17 Aso, K., Uemura, T. \& Shiokawa, Y. Protease-catalyzed synthesis of oligo-L-glutamic acid from L-glutamic acid diethyl ester. Agric. Biol. Chem. 52, 2443-2449 (1988).

18 Baker, P. J. \& Numata, K. Chemoenzymatic synthesis of poly(L-alanine) in aqueous environment. Biomacromolecules 13, 947-951 (2012).

19 Li, G., Vaidya, A., Viswanathan, K., Cui, J., Xie, W., Gao, W. \& Gross, R. A. Rapid regioselective oligomerization of L-glutamic acid diethyl ester catalyzed by papain. Macromolecules 39, 7915-7921 (2006).

20 Viswanathan, K., Omorebokhae, R., Li, G. \& Gross, R. A. Protease-catalyzed oligomerization of hydrophobic amino acid ethyl esters in homogeneous reaction media using L-phenylalanine as a model system. Biomacromolecules 11, 2152-2160 (2010).
21 Narai-Kanayama, A., Shikata, Y., Hosono, M. \& Aso, K. High level production of bioactive di- and tri-tyrosine peptides by protease-catalyzed reactions. J. Biotechnol. 150, 343-347 (2010).

22 Yazawa, K. \& Numata, K. Recent advances in chemoenzymatic peptide syntheses. Molecules 19, 13755-13774 (2014).

23 Christensen, U., DrøHse, H. B. \& MØLgaard, L. Mechanism of carboxypeptidase-Ycatalysed peptide semisynthesis. Eur. J Biochem. 210, 467-473 (1992).

24 Gittel, C. \& Schmidtchen, F. P. Directed N-terminal elongation of unprotected peptides catalyzed by cathepsin C in water. Bioconjug. Chem. 6, 70-76 (1995).

25 Hellio, F., Gueguen, P. \& Morgat, J.-L. Peptide enzymatic microsynthesis, using carboxypeptidase $Y$ as the catalyst: application to stepwise synthesis of Leuenkephalin. Biochimie 70, 791-802 (1988).

26 Numata, K. Poly (amino acid)s/polypeptides as potential functional and structural materials. Polym. J. 116, 34-41 (2015).

27 Mortensen, U. H., Stennicke, H. R., Raaschou-Nielsen, M. \& Breddam, K. Mechanistic study on carboxypeptidase Y-catalyzed transacylation reactions. Mutationally altered enzymes for peptide synthesis. J. Am. Chem. Soc. 33, 508-517 (1994).

28 Thust, S. \& Koksch, B. Discovery of carboxypeptidase $Y$ as a catalyst for the incorporation of sterically demanding $\alpha$-fluoroalkyl amino acids into peptides. Tetrahedron Lett. 45, 1163-1165 (2004).

29 Widmer, F. \& Johansen, J. Enzymatic peptide synthesis. Carboxypeptidase Y catalyzed formation of peptide bonds. Carlsberg Res. Commun. 44, 37-46 (1979).

30 Widmer, F., Breddam, K. \& Johansen, J. Influence of the structure of amine components on carboxypeptidase $\mathrm{Y}$ catalyzed amide bond formation. Carlsberg Res. Commun. 46, 97-106 (1981).

31 Breddam, K. Widmer, F. \& Johansen, J. Influence of the substrate structure on carboxypeptidase $Y$ catalyzed peptide bond formation. Carlsberg Res. Commun. 45, 361-367 (1980).

32 Widmer, F., Breddam, K. \& Johansen, J. Carboxypeptidase Y catalyzed peptide synthesis using amino acid alkyl esters as amine components. Carlsberg Res. Commun. 45, 453-463 (1980).

33 Yu, D., Tian, L., Ma, D., Wu, H., Wang, Z., Wang, L. \& Fang, X. Microwave-assisted fatty acid methyl ester production from soybean oil by Novozym 435. Green Chem. 12, 844-850 (2010).

34 Hayashi, R., Bai, Y. \& Hata, T. Kinetic studies of carboxypeptidase Y: I. Kinetic parameters for the hydrolysis of synthetic substrates. J. Biochem. 77, 69-79 (1975).

35 Mortensen, U. H., Remington, S. J. \& Breddam, K. Site-directed mutagenesis on (serine) carboxypeptidase Y. A hydrogen bond network stabilizes the transition state by interaction with the C-terminal carboxylate group of the substrate. Biochemistry 33, 508-517 (1994).

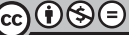

This work is licensed under a Creative Commons Attribution-NonCommercial-NoDerivs $\quad 4.0$ International License. The images or other third party material in this article are included in the article's Creative Commons license, unless indicated otherwise in the credit line; if the material is not included under the Creative Commons license, users will need to obtain permission from the license holder to reproduce the material. To view a copy of this license, visit http://creativecommons.org/licenses/bync-nd/4.0/ 